\title{
Highly Efficient Extraction of Cadmium(II) in Nitrate Medium by Quarternary Ammoniums
}

\author{
Brahim Guezzen, Mohamed Amine Didi* \\ Laboratory of Separation \& Purification Technologies, Department of Chemistry, Tlemcen University, Tlemcen, \\ Algeria \\ Email: ${ }^{*}$ madidi13@yahoo.fr
}

Received 9 August 2015; accepted 20 October 2015; published 23 October 2015

Copyright (C) 2015 by authors and Scientific Research Publishing Inc.

This work is licensed under the Creative Commons Attribution International License (CC BY).

http://creativecommons.org/licenses/by/4.0/

(c) (i) Open Access

\section{Abstract}

The solvent extraction of cadmium(II) from nitrate medium was studied. The using extractants were quaternary ammonium-based room temperature ionic liquid Aliquat 336 in either the chloride $\left[\left(\mathrm{C}_{8} \mathrm{H}_{17}\right)_{3} \mathrm{CH}_{3} \mathrm{~N}^{+} \cdot \mathrm{Cl}^{-}\right]$, thiocyanate $\left[\left(\mathrm{C}_{8} \mathrm{H}_{17}\right)_{3} \mathrm{CH}_{3} \mathrm{~N}^{+} \cdot \mathrm{SCN}^{-}\right]$and hydrogenophosphate $\left[\left(\mathrm{C}_{8} \mathrm{H}_{17}\right)_{3} \mathrm{CH}_{3} \mathrm{~N}^{+} \cdot \mathrm{H}_{2} \mathrm{PO}_{4}^{-}\right]$forms, diluted in the kerosene. The effects of different parameters such as equilibration time, initial $\mathrm{pH}, 0 / \mathrm{A}$ molar ratio $\left(\mathrm{n}_{\text {extractant }} / \mathbf{n}_{\mathrm{Cd}}\right)$, initial extractant concentration and ionic strong on extraction of cadmium(II) were investigated. The extraction yields of cadmium(II) increase with increasing initial $\mathrm{pH}$ and initial extractant concentration. The stoichiometry of the extracted species was determined on the basis of slope analysis. The effect of various salts such as $\mathrm{KSCN}$ and $\mathrm{NaNO}_{3}$ in the feed solution within the concentrations of 10 to $100 \mathrm{mM}$ on extraction of cadmium(II) was studied at optimal initial $\mathrm{pH}=6.2$. The relation between the percentages of the extracted species $\left(\mathrm{Cd}^{2+}, \mathrm{Cd}(\mathrm{SCN})_{3}^{-}, \mathrm{Cd}(\mathrm{SCN})_{4}^{2-}\right.$ and $\left.\mathrm{CdNO}_{3}^{+}\right)$and the extraction yields were investigated by a calculation program using CHEAQS V. L20.1. The results showed that the decrease of the extraction yield of Cd(II) was related with the decrease gradually of percentage of cadmium(II) free and the increase of percentage of $\mathrm{Cd}(\mathrm{SCN})_{3}^{-}$and $\mathrm{Cd}(\mathrm{SCN})_{4}^{2-}$ species with the addition of KSCN. More the hydrophobic character of the extractant is high, more the extraction is better. The metal ion was stripped out satisfactorily using nitric acid as stripping agent, in one step.

\section{Keywords}

Cadmium, Liquid-Liquid Extraction, Ionic Liquid, Aliquat 336, Anion Effect

\footnotetext{
${ }^{*}$ Corresponding author.
}

How to cite this paper: Guezzen, B. and Didi, M.A. (2015) Highly Efficient Extraction of Cadmium(II) in Nitrate Medium by Quarternary Ammoniums. American Journal of Analytical Chemistry, 6, 898-910. 


\section{Introduction}

Industrialization has led to a substantial increase, especially in natural concentrations of the heavy metals in the environment all over the world. Since heavy metals cannot be biodegradable and tend to accumulate in living organisms, their removal from wastewaters is required prior to discharge [1].

Cadmium is known to be both extremely toxic, is present in wastewaters from various industries and ubiquitous in natural environments; however, human activities have greatly increased these levels [1]. Naturally cadmium occurs mainly associated with zinc metallurgical processes, but also lead and copper metallurgical processes, making it an unavoidable by-product when refining these metals.

The critical organ for chronic cadmium exposure has long been considered to be the kidney and the main site of cadmium accumulation is in the proximal tubular cells of the renal cortex. The so called critical effect, the first adverse effect that occurs as the dose increases, is renal tubular dysfunction detected as increased urinary excretion of low-molecular-weight proteins and intracellular tubular enzymes [2] [3]. The Itai-Itai endemic illustrates the contamination of man by this metal, in fact this disease appeared in 1950 in Japan and resulted in a very significant renal impairment associated with osteoporosis (demineralization and weakening of the bones) and symptoms of osteomalacia (demineralization and bone deformities) [4].

The International Agency for Research on Cancer (IARC) has classified cadmium as a human carcinogen because of the large incidence of lung cancers in occupationally exposed populations [5]. Drinking water regulations have continued to lower the maximum contaminant level (MCL) for cadmium based on more information about health effects. The World Health Organization set the tolerance limits for cadmium concentration in drinking water as $3 \mu \mathrm{g} / \mathrm{L}$ [6].

Liquid effluents containing cadmium can be treated using conventional physical and chemical techniques such as, precipitation [7] [8], adsorption [9] [10], dialysis/electro-dialysis [11], supported liquid membrane [12][14], emulsion liquid membrane [15]-[17] and liquid-solid extraction [18]. Solvent extraction is one of the most promising techniques for separation of various metals species including cadmium(II) [19]-[21].

It has been demonstrated that task-specific ionic liquids have advantages compared to common solvents used as separation media in liquid-liquid extraction processes achieving high efficiencies and selectivities of separation. The physic-chemical properties of ionic liquids (ILs) such as the negligible vapor pressure, the miscibility with other solvents, and good solubility of organic and inorganic compounds, are in a medium of choice for solvent extraction techniques [22] [23] as the electrodeposition [24].

Application of ILs in separation of cadmium and their mechanisms have been investigated by several research groups in the past few years. De Los Ríos has studied the extraction of $\mathrm{Zn}, \mathrm{Cd}, \mathrm{Cu}$ and $\mathrm{Fe}$ by methyltrioctylammonium chloride $\left[\mathrm{MTOA}^{+} \cdot \mathrm{Cl}^{-}\right]$and 1-methyl-3-octylimidazolium tetrafluoroborate $\left[\mathrm{OMIm}^{+} \cdot \mathrm{BF}_{4}^{-}\right]$from hydrochloride aqueous solutions [25]. The Recovery of cadmium from ultrapure water and a natural river sample by hydrophobic ionic liquids synthesized from tricaprylmethylammonium chloride was investigated by Kogelnig [26].

A fundamental study assessed the potential of ionic liquids based on quaternary ammonium cations for future applications in advanced sewage treatment and the removal of metals, lanthanides and metalloids like $\mathrm{Cu}, \mathrm{Rh}$, Eu, Ce, Ag, As, Cd, Cr and Hg [27]-[31], and separation of the Ni(II)/Co(II) mixtures [32].

In the present study, the extraction of $\mathrm{Cd}(\mathrm{II})$ in nitrate solution using quaternary ammonium-based room temperature ionic liquid Aliquat 336 in either the chloride, thiocyanate or hydrogenophosphate forms are studied. The effects of equilibration time, initial $\mathrm{pH}\left(\mathrm{pH}_{\mathrm{i}}\right)$, extractant concentration, $\mathrm{O} / \mathrm{A}$ molar ratio $\left(\mathrm{n}_{\text {extractant }} / \mathrm{n}_{\mathrm{Cd}}\right)$, and ionic strong on the extraction systems were studied. Stripping of the metal ion from the organic phases was also investigated.

\section{Experimental}

\subsection{Chemicals and Reagents}

All chemicals and reagents used were analytical reagent grade. Cadmium nitrate, ammonium thiocyanate, potassium thiocyanate, sodium hydrogenophosphate, sodium nitrate, 4-(2-pyridylazo) resorcinol (PAR) and kerosene were provided from Fluka. Buffer solution at $\mathrm{pH}=9.0$ and nitric acid were supplied from Riedel-Dehaen AG. Aliquat 336 chloride was purchased from Merck. 


\subsection{Apparatus}

Analytik Jena SPECORD 210 Double Beam UV-VIS was used for spectra recording and absorbance measurements.

Spectra were recorded in the range from 400 to $800 \mathrm{~nm}$ with $0.2 \mathrm{~nm}$ resolution in $10 \mathrm{~mm}$ quartz cells. Data were processed with WinLab software.

$\mathrm{pH}$ measurements for all solutions were taken on a potentiometer Consort C831, with combined glass electrode, that was calibrated at $\mathrm{pH} 4.00,7.00$ and 10.00 with buffer standards.

\subsection{Preparation of $\left[\left(\mathrm{C}_{8} \mathrm{H}_{17}\right)_{3} \mathrm{CH}_{3} \mathrm{~N}^{+} \cdot \mathrm{SCN}^{-}\right]$and $\left[\left(\mathrm{C}_{8} \mathrm{H}_{17}\right)_{3} \mathrm{CH}_{3} \mathrm{~N}^{+} \cdot \mathrm{H}_{2} \mathrm{PO}_{4}^{-}\right]$}

The synthesis of ILs was performed using published procedure [32]. Aliquat 336 chloride (8.083 g, $20 \mathrm{mM})$ was converted to the thiocyanate and hydrogenophosphate forms by mixing with an aqueous solution of $\mathrm{NH}_{4} \mathrm{SCN}$ $(1.520 \mathrm{~g}, 20 \mathrm{mM})$ and $\mathrm{NaH}_{2} \mathrm{PO}_{4}(3.120 \mathrm{~g}, 20 \mathrm{mM})$ at an $\mathrm{A} / \mathrm{O}$ volume ratio of unity for $2 \mathrm{~h}$ at room temperature $\left(20^{\circ} \mathrm{C} \pm 1^{\circ} \mathrm{C}\right)$. After the extractant solution was mixed well with fresh thiocyanate or hydrogenophosphate solutions, the chloride ions in the extractant were quantitatively replaced by thiocyanate or hydrogenophosphate groups. The removal of the chloride ions was followed by testing the aqueous solution by chloride precipitation using $\mathrm{AgNO}_{3}$ [33]. The viscous liquid was washed three times with $10 \mathrm{~mL}$ of acetone in a separation funnel followed by evaporation.

Hydrophobic character of extractants was evaluated by the logarithmic n-octanol/water partition coefficients (Log P), calculated with Clog P program of the commercial available software ChemDrawultra ${ }^{8.0}$ (Cambridge Soft).

\subsection{Liquid-Liquid Extraction and Stripping Procedure}

Ionic liquid phase in kerosene solvent was mixed and shaken with aqueous solution of cadmium(II) for few minutes which was sufficient for equilibrium. The mixtures were then centrifuged to enhance phase separation. For stripping of metal ion, different concentrations of nitric acid were contacted with the loaded organic phase at an O/A phase volume ratio of 1:1, followed by vigorous shaking to reach equilibrium.

The cadmium concentrations in the aqueous phase were spectrophotometrically determined using 4-(2-pyridylazo) resorcinol (PAR) as a chromogenic reagent at $\mathrm{pH} 9.0$ [34]. The absorbance of PAR-Cd(II) complex was measured at $\lambda_{\max }=496 \mathrm{~nm}$.

The extraction yield Equation (1), the distribution ratio D (2) and stripping percent S (3) were defined as follows:

$$
\begin{gathered}
\% E=\frac{[\mathrm{Cd}]_{i, a q}-[\mathrm{Cd}]_{f, a q}}{[\mathrm{Cd}]_{i, a q}} \times 100 \\
D=\frac{[\mathrm{Cd}]_{i, a q}-[\mathrm{Cd}]_{f, a q}}{[\mathrm{Cd}]_{f, a q}} \cdot \frac{V_{a q}}{V_{\text {org }}} \\
\% S=\frac{[\mathrm{Cd}]_{f, \text { strip }}}{[\mathrm{Cd}]_{i, \text { org }}} \cdot 100
\end{gathered}
$$

where $[\mathrm{Cd}]_{i, a q}$ and $[\mathrm{Cd}]_{f, a q}$ denoted the initial concentration and the equilibrium concentration of cadmium ion in the aqueous phase respectively; $[\mathrm{Cd}]_{\text {; strip }}$ is equilibrium concentration of cadmium in stripping acid and $[\mathrm{Cd}]_{i, \text { org }}$ is initial concentration of cadmium ion in organic phase, respectively.

$V_{a q}$ represented the volume of aqueous phase; $V_{\text {org }}$ represented the volume of organic phase.

All the extraction and stripping experiments were carried out at room temperature $\left(20^{\circ} \mathrm{C} \pm 1^{\circ} \mathrm{C}\right)$. Every experiment was three times repeated.

\section{Results and Discussion}

\subsection{Effect of Contact Time}

To study the effect of mixing time on the extraction of $\mathrm{Cd}(\mathrm{II})$, an aqueous nitrate solution $\left(\mathrm{pH}_{\text {initial }}=6.2\right)$ con- 
taining $1 \mathrm{mM}$ of $\mathrm{Cd}(\mathrm{II})$ and an organic phase of $10 \mathrm{mM}$ and $50 \mathrm{mM}$ Aliquat 336 in kerosene in the forms of chloride $\left[\mathrm{R}_{3} \mathrm{CH}_{3} \mathrm{~N}^{+} \cdot \mathrm{Cl}\right]$, thiocyanate $\left[\mathrm{R}_{3} \mathrm{CH}_{3} \mathrm{~N}^{+} \cdot \mathrm{SCN}^{-}\right]$and hydrogenophosphate $\left[\mathrm{R}_{3} \mathrm{CH}_{3} \mathrm{~N}^{+} \cdot \mathrm{H}_{2} \mathrm{PO}_{4}^{-}\right]$were contacted at a 1:1 phase ratio for various mixing periods of time from $0 \mathrm{~min}$ to $50 \mathrm{~min}$ at $\left(20^{\circ} \mathrm{C} \pm 1^{\circ} \mathrm{C}\right)$, Figure 1 . The data obtained shows that, the extraction of Cd(II) by different Aliquat forms increases with the increase in contact time to reach a maximum extraction percent at $30 \mathrm{~min}$, corresponds to a concentration of $50 \mathrm{mM}$ for the three extractants. This is followed by a slight decrease in the case of $\left[\mathrm{R}_{3} \mathrm{CH}_{3} \mathrm{~N}^{+} \cdot \mathrm{SCN}-\right]$ and $\left[\mathrm{R}_{3} \mathrm{CH}_{3} \mathrm{~N}^{+} \cdot \mathrm{H}_{2} \mathrm{PO}_{4}^{-}\right]$. The decrease in the extraction yield can be explained by the fact that the complex formed between extractant and Cd(II) is thermodynamically less stable. This was also observed by Nayl in extraction and separation of $\mathrm{Co}(\mathrm{II})$ and $\mathrm{Ni}(\mathrm{II})$ from sulfate media with Aliquat 336 in kerosene in the forms of chloride, thiocyanate and sulfate [35].

For a lower concentration of extractant $(10 \mathrm{mM})$, the extraction efficiency was found to increase slowly to reach a maximum value after $20 \mathrm{~min}$. Subsequently, the effects of different parameters on the extraction were carried out at $30 \mathrm{~min}$.

\subsection{Effect of Initial pH}

The extraction of $\mathrm{Cd}(\mathrm{II})$ was studied from aqueous nitrate solutions containing $1 \mathrm{mM}$ metal ion by $50 \mathrm{mM}$ $\left[\mathrm{R}_{3} \mathrm{CH}_{3} \mathrm{~N}^{+} \cdot \mathrm{Cl}^{-}\right],\left[\mathrm{R}_{3} \mathrm{CH}_{3} \mathrm{~N}^{+} \cdot \mathrm{SCN}^{-}\right]$and $\left[\mathrm{R}_{3} \mathrm{CH}_{3} \mathrm{~N}^{+} \cdot \mathrm{H}_{2} \mathrm{PO}_{4}^{-}\right]$after 30 min mixing at a $1: 1$ phase ratio at different initial $\mathrm{pH}$ values ranged from 2.0 to 7.4. As can be seen from Figure 2, extraction of cadmium increases when the initial $\mathrm{pH}$ of the solution was increased to reach a maximum value at initial $\mathrm{pH}=6.2$. Lower extraction yield were obtained by the different extractant forms studied at an initial $\mathrm{pH}$ 7.4.

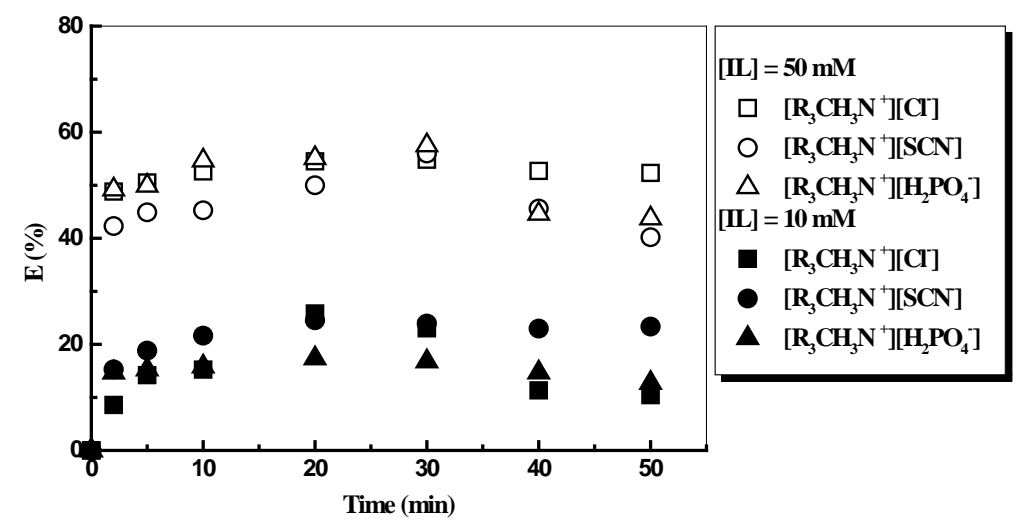

Figure 1. Effect of time on the extraction of Cd(II) from nitrate media by different Aliquat forms. [Cd(II)] $=1 \mathrm{mM}, \mathrm{A} / \mathrm{O}$ phase ratio $=1(\mathrm{v} / \mathrm{v}), \mathrm{pH}_{\text {initial }}=6.2, \mathrm{t}=$ $\left(20^{\circ} \mathrm{C} \pm 1^{\circ} \mathrm{C}\right)$.

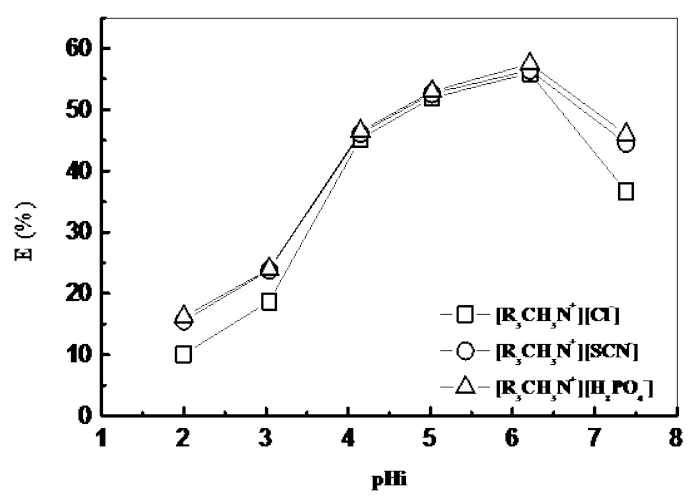

Figure 2. Effect of initial $\mathrm{pH}$ of aqueous solution on the extraction yield of $\mathrm{Cd}(\mathrm{II}) .[\mathrm{IL}]=50 \mathrm{mM},[\mathrm{Cd}(\mathrm{II})]=1 \mathrm{mM}, \mathrm{A} / \mathrm{O}$ phase ratio $=1(\mathrm{v} / \mathrm{v})$, time $=30$ $\min , \mathrm{t}=\left(20^{\circ} \mathrm{C} \pm 1^{\circ} \mathrm{C}\right)$. 
The extraction yield of cadmium is higher for $\left[\mathrm{R}_{3} \mathrm{CH}_{3} \mathrm{~N}^{+} \cdot \mathrm{SCN}{ }^{-}\right]$and $\left[\mathrm{R}_{3} \mathrm{CH}_{3} \mathrm{~N}^{+} \cdot \mathrm{H}_{2} \mathrm{PO}_{4}^{-}\right]$compared to that obtained for $\left[\mathrm{R}_{3} \mathrm{CH}_{3} \mathrm{~N}^{+} \cdot \mathrm{Cl}^{-}\right]$. Thus, the extraction efficiency for the different Aliquat forms is almost the same one in the $\mathrm{pH}_{\text {initial }}$ range from 4.1 to 6.2 .

From Figure 3, it can be seen that maximum cadmium extraction obtained at $\mathrm{pH} 6.2$ could be due to the presence of $\mathrm{Cd}^{2+}$ with a high percentage. The decrease of extraction efficiency to $\mathrm{pH}_{\mathrm{i}}>7.0$ is explained by the fact that the sodium cations from the $\mathrm{NaOH}$ solution (solution used to adjust the $\mathrm{pH}$ ) enters in competition with $\mathrm{Cd}^{2+}$ during the extraction.

\subsection{Effect of IL Concentration}

The effect of Aliquat 336 in the different investigated forms, on the extraction of Cd(II) from aqueous nitrate solution was studied with different extractant concentrations $10-100 \mathrm{mM}$. It was observed that the extraction yield increased with increase of extractant concentration (Figure 4). At $100 \mathrm{mM}$ of extractant concentration, the percentage extraction of cadmium increased up to $71.0 \%, 75.5 \%$ and $85.0 \%$ for $\left[\mathrm{R}_{3} \mathrm{CH}_{3} \mathrm{~N}^{+} \cdot \mathrm{Cl}^{-}\right],\left[\mathrm{R}_{3} \mathrm{CH}_{3} \mathrm{~N}^{+} \cdot \mathrm{SCN}^{-}\right]$ and $\left[\mathrm{R}_{3} \mathrm{CH}_{3} \mathrm{~N}^{+} \cdot \mathrm{H}_{2} \mathrm{PO}_{4}^{-}\right]$, respectively.

The hydrophobic character of extractant can be determinated calculating $\log \mathrm{P}, \log \mathrm{P}$ is definited as the partition coefficient between two phases of a substance, generally n-octanol and water. This parameter developed by Hansch [37] is widely used in medicinal chemistry for QSAR studies, but to our knowledge scarcely used in chemistry. We recently have reported the use of this parameter in the correlation between solubility of reagents

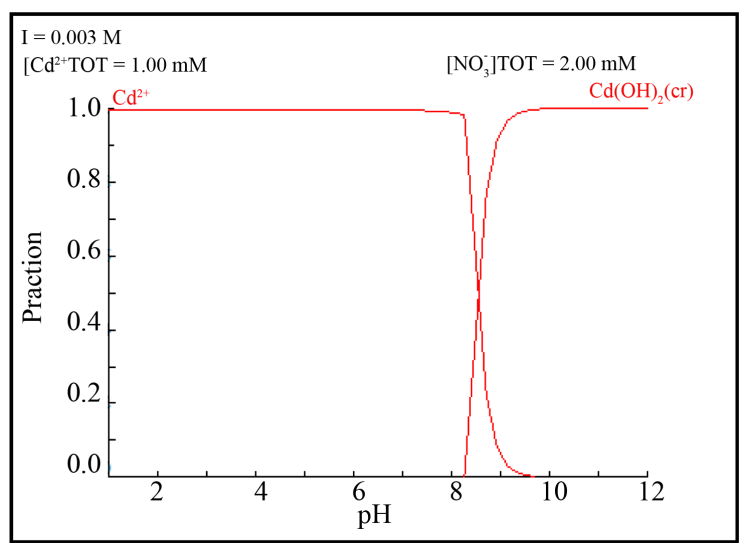

Figure 3. Distribution diagrams of cadmium(II) $(1 \mathrm{mM})$ in nitrate media using Medusa and Hydra programs [36].

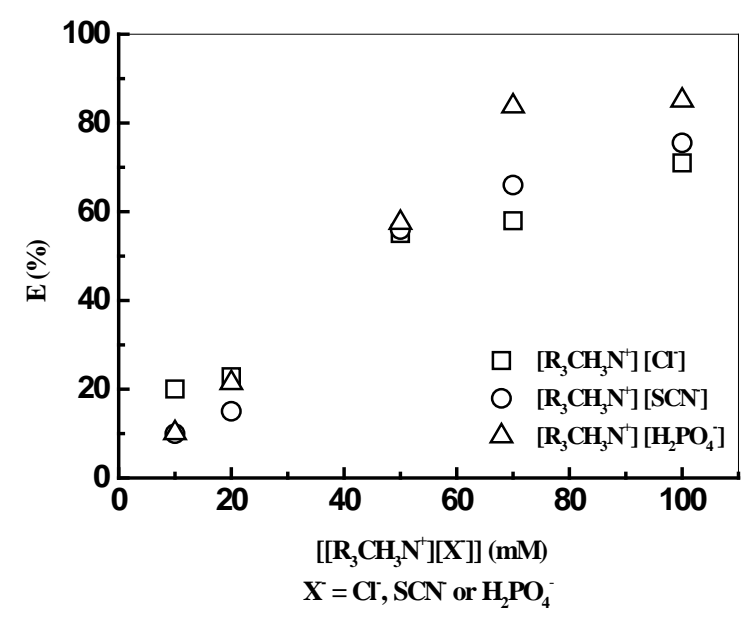

Figure 4. Effect of the ionic liquid concentrations on the cadmium extraction $[\mathrm{Cd}(\mathrm{II})]=1 \mathrm{mM}, \mathrm{pH}_{\text {initial }}=6.2$, time $=$ $30 \mathrm{~min}, \mathrm{~A} / \mathrm{O}$ phase ratio $=1(\mathrm{v} / \mathrm{v}), \mathrm{t}=\left(20^{\circ} \mathrm{C} \pm 1^{\circ} \mathrm{C}\right)$. 
and reactivity in phase transfer Heck reaction [38]. At present, owing to molecular modelisation softwares, log P values can be easily calculated. The Clog $\mathrm{P}$ values, calculated using ChemDraw ultra 8.0 (Cambridge Soft) with Ghose's method [39], were ClogP $=10.001$ for $\left[\left(\mathrm{C}_{8} \mathrm{H}_{17}\right)_{3} \mathrm{CH}_{3} \mathrm{~N}^{+} \cdot \mathrm{H}_{2} \mathrm{PO}_{4}^{-}\right]$, CLogP $=12.938$ for $\left[\left(\mathrm{C}_{8} \mathrm{H}_{17}\right)_{3}\right.$ $\left.\mathrm{CH}_{3} \mathrm{~N}^{+} \cdot \mathrm{SCN}^{-}\right]$and CLogP $=13.562$ for $\left[\left(\mathrm{C}_{8} \mathrm{H}_{17}\right)_{3} \mathrm{CH}_{3} \mathrm{~N}^{+} \cdot \mathrm{Cl}^{-}\right]$. More the hydrophobic character of the extractant is high, more the extraction is better [40]. Further, in the extractant concentration range from $50 \mathrm{mM}-100 \mathrm{mM}$, it is found that the sequence of the extraction of $\mathrm{Cd}(\mathrm{II})$ in terms of the different forms of Aliquat 336 is the following: $\left[\mathrm{R}_{3} \mathrm{CH}_{3} \mathrm{~N}^{+} \cdot \mathrm{H}_{2} \mathrm{PO}_{4}^{-}\right]>\left[\mathrm{R}_{3} \mathrm{CH}_{3} \mathrm{~N}^{+} \cdot \mathrm{SCN}^{-}\right]>\left[\mathrm{R}_{3} \mathrm{CH}_{3} \mathrm{~N}^{+} \cdot \mathrm{Cl}^{-}\right]$.

\subsection{Determination of Stoichiometry of Cd(II)-Organic Complexes}

The experimental data for $\log \mathrm{D}$ versus log different extractants concentrations were plotted in Figure 5 . The plots illustrates the slopes of nearly 1 mole for $\left[\mathrm{R}_{3} \mathrm{CH}_{3} \mathrm{~N}^{+} \cdot \mathrm{Cl}^{-}\right], 3 / 2$ moles for $\left[\mathrm{R}_{3} \mathrm{CH}_{3} \mathrm{~N}^{+} \cdot \mathrm{SCN}^{-}\right]$and 2 moles for $\left[\mathrm{R}_{3} \mathrm{CH}_{3} \mathrm{~N}^{+} \cdot \mathrm{H}_{2} \mathrm{PO}_{4}^{-}\right]$for extraction of one mole of $\mathrm{Cd}(\mathrm{II})$ into the organic phase.

The extraction equation of cadmium in nitrate medium with different Aliquat forms diluted in kerosene can be represented by the proposed equilibrium equations:

$$
\begin{gathered}
\left(\mathrm{Cd}^{2+} \cdot 2 \mathrm{NO}_{3}^{-}\right)_{\mathrm{aq}}+\left[\mathrm{R}_{3} \mathrm{CH}_{3} \mathrm{~N}^{+} \cdot \mathrm{Cl}^{-}\right]_{\mathrm{org}} \rightleftharpoons\left(\mathrm{Cd}\left(\mathrm{NO}_{3}\right)_{2} \cdot\left[\mathrm{R}_{3} \mathrm{CH}_{3} \mathrm{~N}^{+} \cdot \mathrm{Cl}^{-}\right]\right)_{\text {org }} \\
\left(\mathrm{Cd}^{2+} \cdot 2 \mathrm{NO}_{3}^{-}\right)_{\mathrm{aq}}+3 / 2\left(\left[\mathrm{R}_{3} \mathrm{CH}_{3} \mathrm{~N}^{+} \cdot \mathrm{SCN}^{-}\right]\right)_{\mathrm{org}} \rightleftharpoons\left(\mathrm{Cd}\left(\mathrm{NO}_{3}\right)_{2} \cdot 3 / 2\left[\mathrm{R}_{3} \mathrm{NCH}_{3}^{+} \cdot \mathrm{SCN}^{-}\right]\right)_{\text {org }} \\
\left(\mathrm{Cd}^{2+} \cdot 2 \mathrm{NO}_{3}^{-}\right)_{\mathrm{aq}}+2\left(\left[\mathrm{R}_{3} \mathrm{CH}_{3} \mathrm{~N}^{+} \cdot \mathrm{H}_{2} \mathrm{PO}_{4}^{-}\right]\right)_{\mathrm{org}} \rightleftharpoons\left(\mathrm{Cd}\left(\mathrm{NO}_{3}\right)_{2} \cdot 2\left[\mathrm{R}_{3} \mathrm{CH}_{3} \mathrm{~N}^{+} \cdot \mathrm{PO}_{4}^{3-}\right]\right)_{\text {org }}
\end{gathered}
$$

\subsection{Effect of 0/A Molar Ratio}

The molar ratio of organic to aqueous $(\mathrm{O} / \mathrm{A})$ in solvent extraction process plays important role for the extraction of metals from solutions. Therefore, the studies were made by varying O/A molar ratio between 1 and 100, for the extraction of $\mathrm{Cd}(\mathrm{II})$ from the aqueous feed solution containing $1 \mathrm{mM}$ of metal ion $(\mathrm{A} / \mathrm{O}$ volume phase ratio = 1). As shown in Figure 6, the extraction yield (E) of Cd(II) increased with the increasing of the molar ratio and the percentage extraction with the $\left[\mathrm{R}_{3} \mathrm{CH}_{3} \mathrm{~N}^{+} \cdot \mathrm{H}_{2} \mathrm{PO}_{4}^{-}\right]$was higher than the $\left[\mathrm{R}_{3} \mathrm{CH}_{3} \mathrm{~N}^{+} \cdot \mathrm{Cl}^{-}\right]$and $\left[\mathrm{R}_{3} \mathrm{CH}_{3} \mathrm{~N}^{+} \cdot \mathrm{SCN}^{-}\right]$. The percentage extraction of cadmium in the range of molar ratio between 1 to 100 varied from $2.7 \%$ to $71.0 \%$, $16.2 \%$ to $75.5 \%$ and $16.5 \%$ to $85.0 \%$ in $\left[\mathrm{R}_{3} \mathrm{CH}_{3} \mathrm{~N}^{+} \cdot \mathrm{Cl}^{-}\right],\left[\mathrm{R}_{3} \mathrm{CH}_{3} \mathrm{~N}^{+} \cdot \mathrm{SCN}^{-}\right]$and $\left[\mathrm{R}_{3} \mathrm{CH}_{3} \mathrm{~N}^{+} \cdot \mathrm{H}_{2} \mathrm{PO}_{4}^{-}\right]$extraction system respectively.

\subsection{Effect of Salts}

As the nitrates and alkali ions frequently accompany metal ion in industrial solutions, it is worthwhile to know if

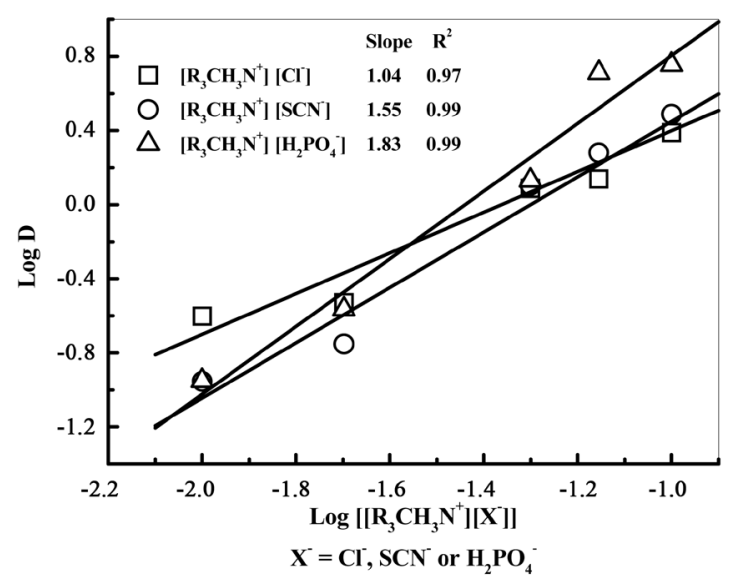

Figure 5. Effect of ionic liquid concentration on the distribution coefficient of cadmium $[\mathrm{Cd}(\mathrm{II})]=1 \mathrm{mM}, \mathrm{pH}_{\text {initial }}=6.2$, time $=30 \mathrm{~min}, \mathrm{~A} / \mathrm{O}$ phase ratio $=1(\mathrm{v} / \mathrm{v}), \mathrm{t}=\left(20^{\circ} \mathrm{C} \pm 1^{\circ} \mathrm{C}\right)$. 
they affect the extraction process efficiency. To study the effect of salts such as $\mathrm{KSCN}, \mathrm{NaNO}_{3}$ on the extraction of $\mathrm{Cd}(\mathrm{II})$ from the nitrate solution, extractions were carried out with $1 \mathrm{mM}$ metal ion at equal phase ratio. The concentrations of the salts in the aqueous solution and Aliquat 336 in the different investigated forms were varied within the range 10 to $100 \mathrm{mM}$. From Figure 7, the results obtained showed that the KSCN almost had positive effect on the extraction efficiency of the cadmium ion. The extraction yield of Cd(II), with $10 \mathrm{mM}$ of extractant in the range of KSCN concentration between 0 (without addition) to $10 \mathrm{mM}$, varied from $20 \%$ to $85.9 \%, 10 \%$ to $58.1 \%, 10.1 \%$ to $69.8 \%$ in $\left[\mathrm{R}_{3} \mathrm{CH}_{3} \mathrm{~N}^{+} \cdot \mathrm{Cl}^{-}\right],\left[\mathrm{R}_{3} \mathrm{CH}_{3} \mathrm{~N}^{+} \cdot \mathrm{SCN}-\right]$ and $\left[\mathrm{R}_{3} \mathrm{CH}_{3} \mathrm{~N}^{+} \cdot \mathrm{H}_{2} \mathrm{PO}_{4}^{-}\right]$extraction system respectively. However, the increase of the KSCN concentration from $10 \mathrm{mM}$ to $100 \mathrm{mM}$ has little effect on the extraction efficiency of Cd(II) with $\left[\mathrm{R}_{3} \mathrm{CH}_{3} \mathrm{~N}^{+} \cdot \mathrm{H}_{2} \mathrm{PO}_{4}^{-}\right]$and $\left[\mathrm{R}_{3} \mathrm{CH}_{3} \mathrm{~N}^{+} \cdot \mathrm{Cl}^{-}\right]$in the field of concentration between 50 to $100 \mathrm{mM}$. Thus one can affirm that the extraction of cadmium(II) by Aliquat 336 in the different investigated forms depends on the ionic strength in aqueous medium until saturation.

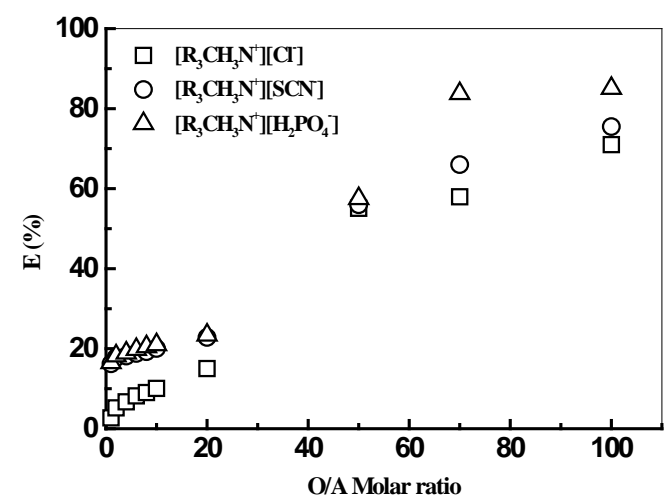

Figure 6. Influence of the $\mathrm{O} / \mathrm{A}$ molar ratio on the extraction yield $[\mathrm{Cd}(\mathrm{II})]=1 \mathrm{mM}, \mathrm{pH}_{\text {initial }}=6.2$, time $=30$ min, $\mathrm{A} / \mathrm{O}$ phase ratio $=1(\mathrm{v} / \mathrm{v}), \mathrm{t}=\left(20^{\circ} \mathrm{C} \pm 1^{\circ} \mathrm{C}\right)$.

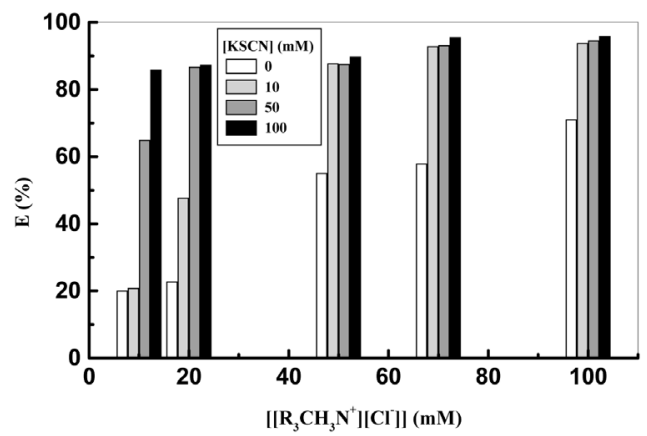

(a)

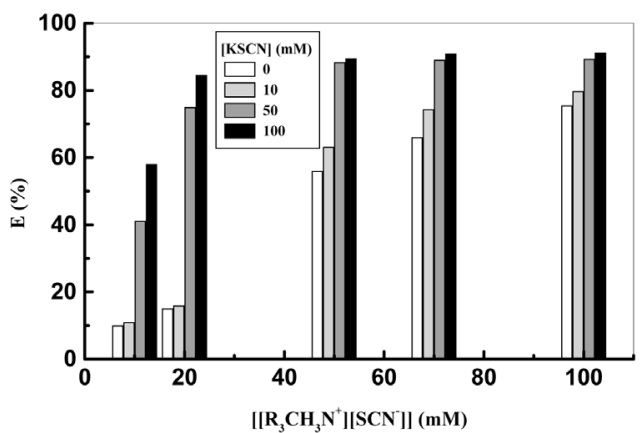

(b)

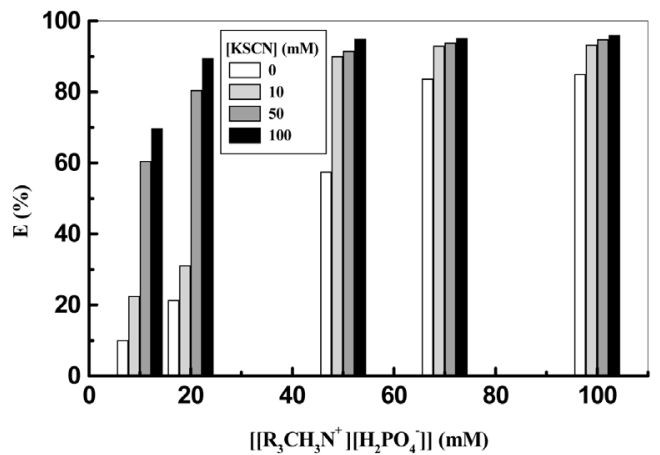

(c)

Figure 7. Comparative study to effect of KSCN on the cadmium extraction with Aliquat 336 in the different investigated forms. $[\mathrm{Cd}(\mathrm{II})]=1 \mathrm{mM}, \mathrm{pH}_{\text {initial }}=6.2$, time $=30 \mathrm{~min}, \mathrm{~A} / \mathrm{O}$ phase ratio $=1(\mathrm{v} / \mathrm{v}), \mathrm{t}=\left(20^{\circ} \mathrm{C} \pm 1^{\circ} \mathrm{C}\right)$. 
The results in Figure 8(a) show that the addition of $\mathrm{NaNO}_{3}$ increases the extraction yield for very concentrated solutions of $\left[\mathrm{R}_{3} \mathrm{CH}_{3} \mathrm{~N}^{+} \cdot \mathrm{Cl}^{-}\right]$: for extractant concentration equal to $50 \mathrm{mM}$ the extraction yield of $\mathrm{Cd}(\mathrm{II})$ in the range of $\mathrm{NaNO}_{3}$ concentration between 0.0 (without addition) to $100 \mathrm{mM}$, varied from $55.1 \%$ to $80.6 \%$ and from $71.0 \%$ to $86.5 \%$ for extractant concentration equal to $100 \mathrm{mM}$. On the other hand, with dilute extractant concentrations ( 10 and $20 \mathrm{mM}$ ) decreases in extraction yields were observed by the addition of $50 \mathrm{mM}$ of Na$\mathrm{NO}_{3}$. The observed negative effect on $\mathrm{Cd}(\mathrm{II})$ extraction can be explained in terms of a competition with sodium cation. According to Figure 8(b), at salt concentrations of 10 and $100 \mathrm{mM}$, increased extraction efficiency was observed. For the extraction system $\left[\mathrm{R}_{3} \mathrm{CH}_{3} \mathrm{~N}^{+} \cdot \mathrm{H}_{2} \mathrm{PO}_{4}^{-}\right]$at concentrations $\geq 50 \mathrm{mM}$, the addition of $\mathrm{NaNO}_{3}$ at low concentrations $(10 \mathrm{mM}$ ) leads to a significant decrease in $\mathrm{Cd}(\mathrm{II})$ extraction (Figure 8(c)).

The results found by calculation program using CHEAQS V. L20.1 are summarized in Table 1 and Table 2.

The results of Table 1, enable us to observe that the species having an outstanding influence on the yield extraction, during the variation of the concentration in $\mathrm{KSCN}$, are free $\mathrm{Cd}^{2+}$ ions and the anion molecules $\mathrm{Cd}(\mathrm{SCN})_{3}^{-}$and $\mathrm{Cd}(\mathrm{SCN})_{4}^{2-}$. It can be seen that the decrease of the extraction yield of $\mathrm{Cd}(\mathrm{II})$ is related with the decrease gradually of percentage of $\mathrm{Cd}(\mathrm{SCN})_{3}^{-}$and $\mathrm{Cd}(\mathrm{SCN})_{4}^{2-}$.

In the case of the extractant $\left[\mathrm{R}_{3} \mathrm{CH}_{3} \mathrm{~N}^{+} \cdot \mathrm{SCN}^{-}\right]$, the increase in concentration of KSCN from 0.0 (without addition) to $100 \mathrm{mM}$, in the same experimental conditions, increases the extraction yield from $57.5 \%$ to $94.9 \%$. This increase is related with the decrease gradually of percentage of $\mathrm{Cd}(\mathrm{SCN})_{3}^{-}$and $\mathrm{Cd}(\mathrm{SCN})_{4}^{2-}$ species from $0 \%$ to $80.5 \%$ and from $0 \%$ to $16.1 \%$ respectively, followed by a drastic decrease of free $\mathrm{Cd}^{2+}$ ions from $100 \%$ to $0 \%$ (Figure 9).

The results given in Table 2 and Figure 10, shows that the extraction yield with different Aliquat forms increases with increasing concentration of $\mathrm{NaNO}_{3}$, resulting in an increasing rate of $\mathrm{CdNO}_{3}^{+}$species and a relative decrease of free $\mathrm{Cd}^{2+}$ ions.

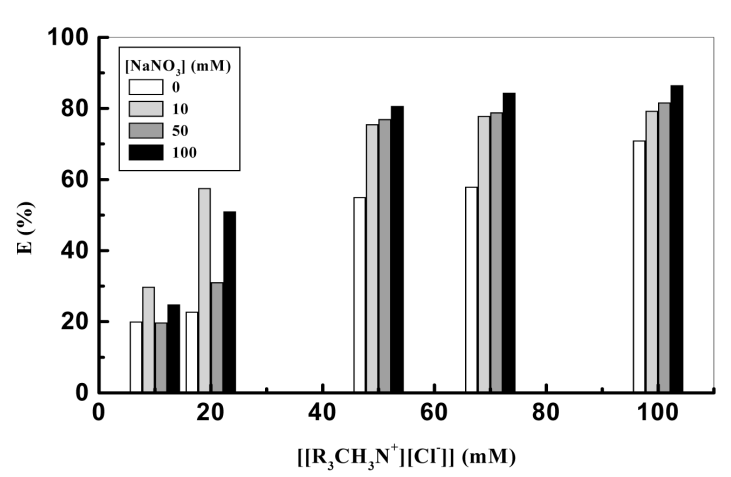

(a)

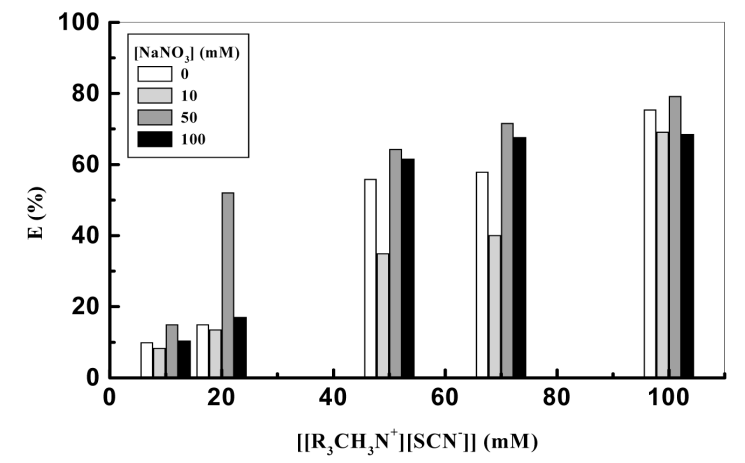

(b)

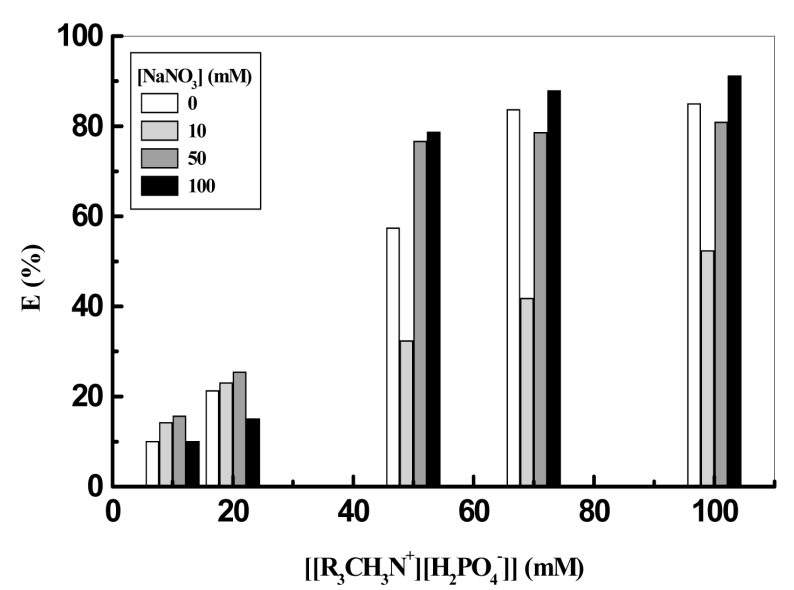

(c)

Figure 8. Comparative study to effect of $\mathrm{NaNO}_{3}$ on the cadmium extraction with Aliquat 336 in the different investigated forms. $[\mathrm{Cd}(\mathrm{II})]=1 \mathrm{mM}, \mathrm{pH}_{\text {initial }}=6.2$, time $=30 \mathrm{~min}, \mathrm{~A} / \mathrm{O}$ phase ratio $=1(\mathrm{v} / \mathrm{v}), \mathrm{t}=\left(20^{\circ} \mathrm{C} \pm 1^{\circ} \mathrm{C}\right)$. 


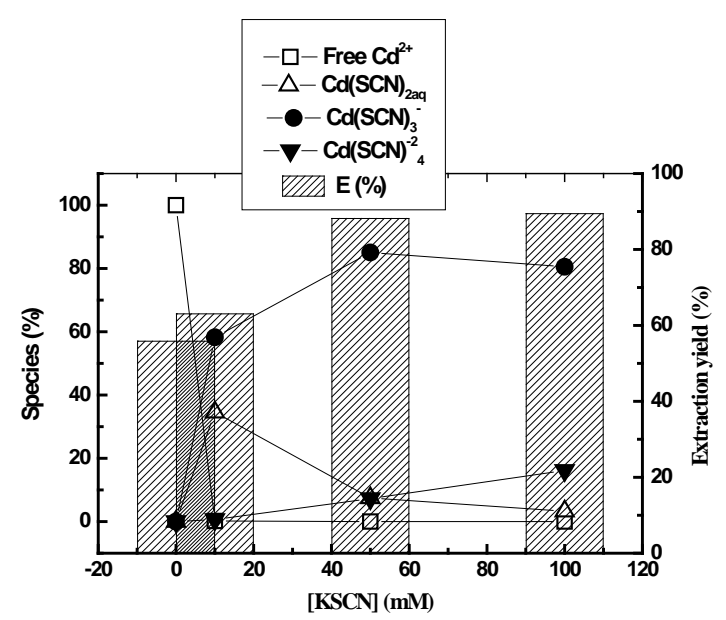

Figure 9. Variation rate of chemical species present in the feed phase and the extraction yield of Cd (II) with $\left[\mathrm{R}_{3} \mathrm{CH}_{3} \mathrm{~N}^{+} \cdot \mathrm{SCN}^{-}\right]$depending on the concentration of KSCN. A/O phase ratio $=1(\mathrm{v} / \mathrm{v}),[\mathrm{IL}]=50 \mathrm{mM},[\mathrm{Cd}(\mathrm{II})]=1 \mathrm{mM}, \mathrm{t}=$ $\left(20^{\circ} \mathrm{C} \pm 1^{\circ} \mathrm{C}\right)$.

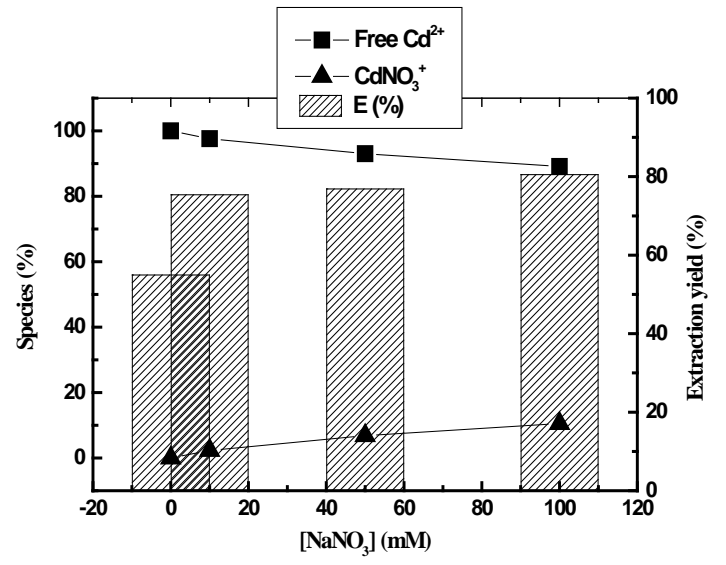

Figure 10. Variation rate of chemical species present in the feed phase and the extraction yield of Cd(II) with $\left[\mathrm{R}_{3} \mathrm{CH}_{3} \mathrm{~N}^{+} \cdot \mathrm{Cl}^{-}\right]$ depending on the concentration of $\mathrm{NaNO}_{3}$.

Table 1. Nature and percentages of extracted species at different concentration of KSCN. [IL] = $50 \mathrm{mM},[\mathrm{Cd}(\mathrm{II})]=1 \mathrm{mM}$.

\begin{tabular}{ccccccccc}
\hline \multirow{2}{*}{$\begin{array}{c}\text { KSCN }] \\
(\mathrm{mM})\end{array}$} & \multicolumn{3}{c}{ Extraction yield (\%) } & \multicolumn{4}{c}{ Species (\%) } \\
\cline { 2 - 8 } & {$\left[\mathrm{R}_{3} \mathrm{CH}_{3} \mathrm{~N}^{+} \cdot \mathrm{Cl}^{-}\right]$} & {$\left[\mathrm{R}_{3} \mathrm{CH}_{3} \mathrm{~N}^{+} \cdot \mathrm{SCN}^{-}\right]$} & {$\left[\mathrm{R}_{3} \mathrm{CH}_{3} \mathrm{~N}^{+} \cdot \mathrm{H}_{2} \mathrm{PO}_{4}^{-}\right]$} & $\mathrm{Cd}^{2+}$ & $\mathrm{Cd}(\mathrm{SCN})_{2 \mathrm{qq}}$ & $\mathrm{Cd}(\mathrm{SCN})_{3}^{-}$ & $\mathrm{Cd}(\mathrm{SCN})_{4}^{2-}$ \\
\hline 0.0 & 55.1 & 55.9 & 57.5 & 100 & 0.0 & 0.0 & 0.0 \\
10 & 87.7 & 63.2 & 90.1 & 0.2 & 34.6 & 58.3 & 0.6 \\
50 & 87.6 & 88.3 & 91.6 & 0.0 & 7.5 & 85,0 & 7.3 \\
100 & 89.7 & 89.6 & 94.9 & 0.0 & 3.3 & 80.5 & 16.1 \\
\hline
\end{tabular}

Table 2. Nature and percentages of extracted species at different concentration of $\mathrm{NaNO}_{3}$. [IL] $=50 \mathrm{mM},[\mathrm{Cd}(\mathrm{II})]=1 \mathrm{mM}$.

\begin{tabular}{|c|c|c|c|c|c|}
\hline \multirow{2}{*}{$\begin{array}{c}{\left[\mathrm{NaNO}_{3}\right]} \\
(\mathrm{mM})\end{array}$} & \multicolumn{3}{|c|}{ Extraction yield (\%) } & \multicolumn{2}{|c|}{ Species (\%) } \\
\hline & {$\left[\mathrm{R}_{3} \mathrm{CH}_{3} \mathrm{~N}^{+} \cdot \mathrm{Cl}^{-}\right]$} & {$\left[\mathrm{R}_{3} \mathrm{CH}_{3} \mathrm{~N}^{+} \cdot \mathrm{SCN}^{-}\right]$} & {$\left[\mathrm{R}_{3} \mathrm{CH}_{3} \mathrm{~N}^{+} \cdot \mathrm{H}_{2} \mathrm{PO}_{4}^{-}\right]$} & $\mathrm{Cd}^{2+}$ & $\mathrm{CdNO}_{3}^{+}$ \\
\hline 0.0 & 55.1 & 55.9 & 57.5 & 100 & 0.0 \\
\hline 10 & 75.5 & 35.0 & 32.5 & 97.6 & 2.3 \\
\hline 50 & 77.0 & 64.4 & 76.7 & 93.0 & 6.8 \\
\hline 100 & 80.6 & 61.6 & 78.8 & 89.1 & 10.5 \\
\hline
\end{tabular}




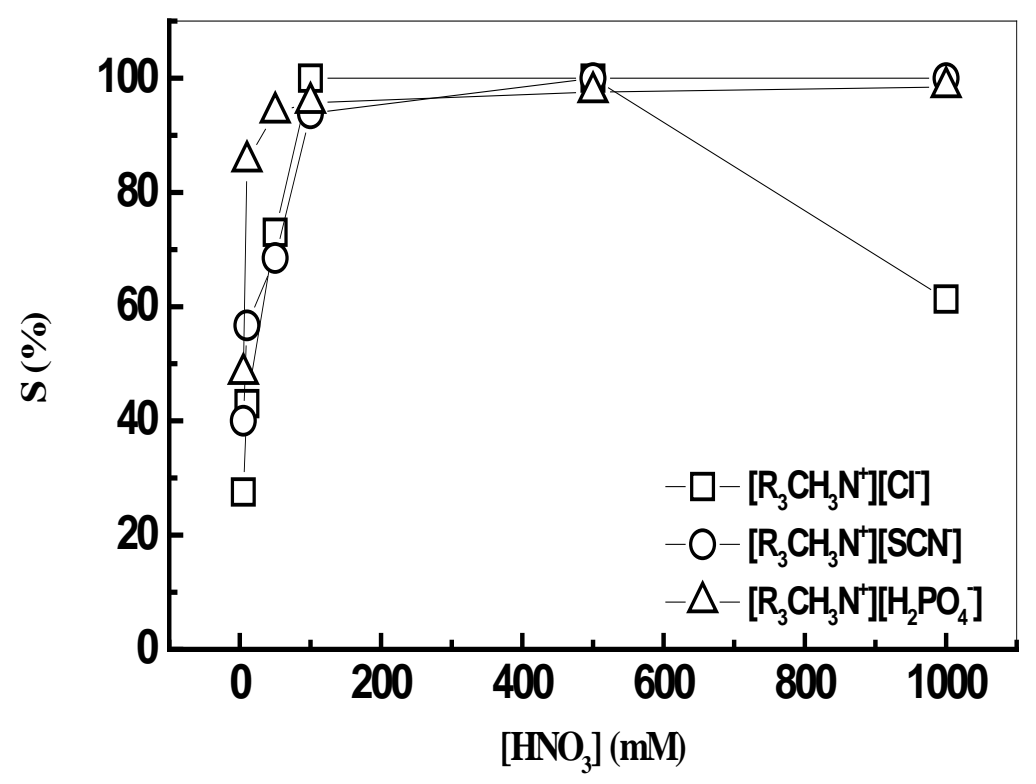

Figure 11. Effect of $\mathrm{HNO}_{3}$ concentration on cadmium stripping (S\%). Time $=30$ $\min , \mathrm{A} / \mathrm{O}$ phase ratio $=1(\mathrm{v} / \mathrm{v}), \mathrm{t}=\left(20^{\circ} \mathrm{C} \pm 1{ }^{\circ} \mathrm{C}\right)$.

\subsection{Cadmium Stripping}

Stripping studies were carried out on organic solution consisting of $50 \mathrm{mM}$ of ionic liquid in kerosene after extraction of $1 \mathrm{mM}$ of $\mathrm{Cd}(\mathrm{II})$ from nitrate media of initial $\mathrm{pH}=6.2$. The loaded organic was stripped using nitric acid. Different concentrations of nitric acid were contacted with the loaded organic phase at an $\mathrm{A} / \mathrm{O}$ phase ratio of $1: 1(\mathrm{v} / \mathrm{v})$ and the results are given in Figure 11. The results showed that the stripping efficiency of $\mathrm{Cd}(\mathrm{II})$ increased with the increasing of the concentration of $\mathrm{HNO}_{3}$. Anionic species of $\mathrm{Cd}(\mathrm{II})$ in the organic phase, while stripped with nitric acid, significantly change their coordination sphere and transform into cationic species in the final aqueous solution [41]. The effect of $\mathrm{HNO}_{3}$ concentration in the range $5-1000 \mathrm{mM}$ showed that $98.5 \%$ stripping efficiency of $\mathrm{Cd}(\mathrm{II})$ from the loaded $\left[\mathrm{R}_{3} \mathrm{CH}_{3} \mathrm{~N}^{+} \cdot \mathrm{H}_{2} \mathrm{PO}_{4}^{-}\right]$is possible in one stage with $1000 \mathrm{mM}$ $\mathrm{HNO}_{3}$. The metal ion is practically completely removed from the loaded $\left[\mathrm{R}_{3} \mathrm{CH}_{3} \mathrm{~N}^{+} \cdot \mathrm{Cl}^{-}\right]$and $\left[\mathrm{R}_{3} \mathrm{CH}_{3} \mathrm{~N}^{+} \cdot \mathrm{SCN}^{-}\right]$ with nitric acid $100 \mathrm{mM}$ and $500 \mathrm{mM}$ respectively. Thus the data obtained show that dilute $\mathrm{HNO}_{3}(<50 \mathrm{mM})$ can be considered as good stripping agent of Cd(II) from the loaded $\left[\mathrm{R}_{3} \mathrm{CH}_{3} \mathrm{~N}^{+} \cdot \mathrm{H}_{2} \mathrm{PO}_{4}^{-}\right]$compared to that obtained from the other loaded organic phase.

\section{Conclusions}

The solvent extraction of cadmium in nitrate medium by quarternary ammonium-based ionic liquids has been studied and following conclusions may be drawn from the above studies.

- The percentage cadmium extraction with these three extractants follows the order $\left[\mathrm{R}_{3} \mathrm{CH}_{3} \mathrm{~N}^{+} \cdot \mathrm{H}_{2} \mathrm{PO}_{4}^{-}\right]>$ $\left[\mathrm{R}_{3} \mathrm{CH}_{3} \mathrm{~N}^{+} \cdot \mathrm{SCN}^{-}\right]>\left[\mathrm{R}_{3} \mathrm{CH}_{3} \mathrm{~N}^{+} \cdot \mathrm{Cl}^{-}\right]$.

- More the hydrophobic character of the extractant is high, more the extraction is better.

- The stoichiometry of the complex between extractant and Cd(II) in the liquid-liquid extraction system was confirmed by the results of slope analysis.

- It has been demonstrated that the yield of $\mathrm{Cd}(\mathrm{II})$ extraction with quarternary ammonium-based ionic liquids from nitrate solutions containing $\mathrm{NaNO}_{3}$ or KSCN depends mainly on the ionic strength of the aqueous phase.

- In the stripping studies, the stripping efficiency of Cd(II) increased with the increasing of the concentration of $\mathrm{HNO}_{3}$. Quantitative extraction of Cd (II) was obtained in one stage at equal phase ratio from the loaded $\left[\mathrm{R}_{3} \mathrm{CH}_{3} \mathrm{~N}^{+} \cdot \mathrm{Cl}^{-}\right]$and $\left[\mathrm{R}_{3} \mathrm{CH}_{3} \mathrm{~N}^{+} \cdot \mathrm{SCN}^{-}\right]$with nitric acid $100 \mathrm{mM}$ and $500 \mathrm{mM}$ respectively.

- The liquid/liquid extraction demonstrated that we can achieve good levels of extraction of $\mathrm{Cd}(\mathrm{II})$ with ionic liquids based on quaternary ammonium. 


\section{Acknowledgements}

We gratefully acknowledge the ATRST (Agence Thématique de Recherche en Sciences \& Technologie-Algérie) (ex. ANDRU) for this financial support.

\section{References}

[1] Larison, J.R., Likens, G.E., Fitzpatrick, J.W. and Crock, G. (2000) Cadmium Toxicity among Wildlife in the Colorado Rocky Mountains. Nature, 406, 181-183. http://dx.doi.org/10.1038/35018068

[2] Bernard, A. (2004) Renal Dysfunction Induced by Cadmium: Biomarkers of Critical Effects. Biometals, 17, 519-523. http://dx.doi.org/10.1023/B:BIOM.0000045731.75602.b9

[3] Barbier, O., Dauby, A., Jacquillet, G., Tauc, M., Poujeol, P. and Cougnon M. (2005) Zinc and Cadmium Interactions in a Renal Cell Line Derived from Rabbit Proximal Tubule. Nephron Physiology, 99, 74-84. http://dx.doi.org/10.1159/000083413

[4] Järup, L. and Åkesson, A. (2009) Current Status of Cadmium as an Environmental Health Problem. Toxicology and Applied Pharmacology, 238, 201-208. http://dx.doi.org/10.1016/j.taap.2009.04.020

[5] European Commission (2007) European Union Risk Assessment Report. Cadmium Metal and Oxide. CAS No. 744043-9. http://publications.jrc.ec.europa.eu/repository/handle/111111111/10936

[6] Xu, Y.P., Yang, L.S. and Yang, J.K. (2010) Removal of Cadmium (II) from Aqueous Solutions by Two Kinds of Manganese Coagulants. International Journal of Environmental Science and Technology, 2, 1-8.

[7] Islamoglu, S., Yilmaz, L. and Ozbelge, H.O. (2006) Development of a Precipitation Based Separation Scheme for Selective Removal and Recovery of Heavy Metals from Cadmium Rich Electroplating Industry Effluents. Separation Science and Technology, 41, 3367-3385. http://dx.doi.org/10.1080/01496390600851665

[8] Lin, X., Burns, R.C. and Lawrance, G.A. (2005) Heavy Metals in Wastewater: The Effect of Electrolyte Composition on the Precipitation of Cadmium(II) Using Lime and Magnesia. Water, Air, \& Soil Pollution, 165, 131-152. http://dx.doi.org/10.1007/s11270-005-4640-9

[9] Abderrahim, O., Ferrah, N., Didi, M.A. and Villemin, D. (2013) Sorption Efficiency of a New Sorbent towards Cadmium (II): Methylphosphonic Acid Grafted Polystyrene Resin. Journal of Chemistry, 2013, 10-20.

[10] Kalfa, O.M., Yalçınkaya, Ö. and Türker, A.R. (2009) Synthesis of Nano $\mathrm{B}_{2} \mathrm{O}_{3} / \mathrm{TiO}_{2}$ Composite Material as a New Solid Phase Extractor and Its Application to Preconcentration and Separation of Cadmium. Journal of Hazardous Materials, 166, 455-461. http://dx.doi.org/10.1016/j.jhazmat.2008.11.112

[11] Marder, L., Guilherme, O.S., Andrea, M.B. and Jane, Z.F. (2003) Removal of Cadmium and Cyanide from Aqueous Solutions through Electrodialysis. Journal of the Brazilian Chemical Society, 14, 610-615. http://dx.doi.org/10.1590/S0103-50532003000400018

[12] Belkhouche, N., Didi, M.A., Romero, R., Jönsson, J.A. and Villemin, D. (2006) Study of New Organophosphorus Derivates Carriers on the Selective Recovery of M (II) and M (III) Metals, Using Supported Liquid Membrane Extraction. Journal of Membrane Science, 284, 398-405. http://dx.doi.org/10.1016/j.memsci.2006.08.011

[13] Belkhouche, N. and Didi, M.A. (2007) Flat Sheet Supported Liquid Membrane Extraction Using Organophosphorus Carriers. 2nd Ain Shams University International Conference on Environmental Engineering, Vol. IV, Caira, 10-12 April 2007, 363-373.

[14] Medjahed, B., Didi, M.A. and Villemin, D. (2014) Factorial Design in Optimization of Extraction Procedure for Copper (II) Using Aliquat 336 and Tri-n-Butylphosphate Based Supported Liquid Membrane. Desalination and Water Treatment, 52, 3237-3245. http://dx.doi.org/10.1080/19443994.2013.797626

[15] Kumbasar, R.A. (2009) Extraction and Concentration Study of Cadmium from Zinc Plant Leach Solutions by Emulsion Liquid Membrane Using Trioctylamine as Extractant. Hydrometallurgy, 95, 290-296. http://dx.doi.org/10.1016/j.hydromet.2008.07.001

[16] Mortaheb, H.R., Kosuge, H., Mokhtarani, B., Amini, M.H. and Banihashemi, H.R. (2009) Study on Removal of Cadmium from Wastewater by Emulsion Liquid Membrane. Journal of Hazardous Materials, 165, 630-636. http://dx.doi.org/10.1016/j.jhazmat.2008.10.039

[17] Ahmad, A.L., Kusumastuti, A., Derek, C.J.C. and Ooi, B.S. (2012) Emulsion Liquid Membrane for Cadmium Removal: Studies on Emulsion Diameter and Stability. Desalination, 287, 30-34. http://dx.doi.org/10.1016/j.desal.2011.11.002

[18] Amara-Rekkab, A. and Didi, M.A. (2015) Removal of Cd (II) and Hg(II) by Chelating Resin Chelex-100. Oriental Journal of Chemistry, 31, 205-214. http://dx.doi.org/10.13005/ojc/310122

[19] Bidari, E., Irannejad, M. and Gharabaghi, M. (2013) Solvent Extraction Recovery and Separation of Cadmium and 
Copper from Sulphate Solution. Journal of Environmental Chemical Engineering, 1, 1269-1274. http://dx.doi.org/10.1016/j.jece.2013.09.016

[20] Nogueira, C.A., Oliveira, P.C. and Pedrosa, F.M. (2009) Separation of Cadmium, Cobalt, and Nickel by Solvent Extraction Using the Nickel Salts of the Extractants. Solvent Extraction and Ion Exchange, 27, 295-311. http://dx.doi.org/10.1080/07366290802672352

[21] Kumar Jha, M., Gupta, D., Kumar Choubey, P., Kumar, V., Jeong, J. and Lee, J. (2014) Solvent Extraction of Copper, Zinc, Cadmium and Nickel from Sulfate Solution in Mixer Settler Unit (MSU). Separation and Purification Technology, 122, 119-127. http://dx.doi.org/10.1016/j.seppur.2013.10.045

[22] Villemin, D. and Didi, M.A. (2013) Extraction of Rare Earth and Heavy Metals, Using Ionic Solvents as Extraction Medium (A Review). Oriental Journal of Chemistry, 29, 1267-1284. http://dx.doi.org/10.13005/ojc/290402

[23] Pandey, S. (2006) Analytical Applications of Room Temperature Ionic Liquids: A Review of Recent Efforts. Analytica Chimica Acta, 556, 38-45. http://dx.doi.org/10.1016/j.aca.2005.06.038

[24] Abbott, A.P. and McKenzie, K.J. (2006) Application of Ionic Liquids to the Electrodeposition of Metals. Physical Chemistry Chemical Physics, 8, 4265-4279. http://dx.doi.org/10.1039/b607329h

[25] De Los Ríos, A.P., Hernández-Fernández, F.J., Alguacil, F.J., Lozano, L.J., Ginestá, A., García-Díaz, I., Sánchez-Segado, S., López, F.A. and Godínez, C. (2012) On the Use of Imidazolium and Ammonium-Based Ionic Liquids as Green Solvents for the Selective Recovery of Zn(II), Cd(II), Cu(II) and Fe(III) from Hydrochloride Aqueous Solutions. Separation and Purification Technology, 97, 150-157. http://dx.doi.org/10.1016/j.seppur.2012.02.040

[26] Kogelnig, D., Stojanovic, A., Galanski, M., Groessl, M., Jirsa, F., Krachler, R. and Keppler, B.K. (2008) Greener Synthesis of New Ammonium Ionic Liquids and Their Potential as Extracting Agents. Tetrahedron Letters, 49, $2782-2785$. http://dx.doi.org/10.1016/j.tetlet.2008.02.138

[27] Castillo, J., Coll, M.T., Fortuny, A., Donoso, P.N., Sepúlveda, R. and Sastre, A.M. (2014) Cu(II) Extraction Using Quaternary Ammonium and Quaternary Phosphonium Based Ionic Liquid. Hydrometallurgy, 141, 89-96. http://dx.doi.org/10.1016/j.hydromet.2013.11.001

[28] Bell, T.J. and Ikeda, Y. (2012) Efficient Extraction of Rh(III) from Nitric Acid Medium Using a Hydrophobic Ionic Liquid. Dalton Transactions, 41, 4303-4305. http://dx.doi.org/10.1039/c2dt30089c

[29] Rout, A., Venkatesan, K.A., Srinivasan, T.G. and Vasudeva Rao, P.R. (2012) Ionic Liquid Extractants in Molecular Diluents: Extraction Behavior of Europium (III) in Quarternary Ammonium-Based Ionic Liquids. Separation and Purification Technology, 95, 26-31. http://dx.doi.org/10.1016/j.seppur.2012.04.020

[30] Villemin, D. and Didi, M.A. (2013) Extraction of Rare Earth and Heavy Metals, Using Ionic Solvents as Extraction Medium (A Review). Oriental Journal of Chemistry, 29, 1267-1284. http://dx.doi.org/10.13005/ojc/290402

[31] Zhang, D.L., Wang, W., Deng, Y.F., Zhang, J.P., Zhao, H. and Chen, J. (2012) Extraction and Recovery of Cerium(IV) and Fluorine(I) from Sulfuric Solutions Using Bifunctional Ionic Liquid Extractants. Chemical Engineering Journal, 179, 19-25. http://dx.doi.org/10.1016/j.cej.2011.06.021

[32] Didi, M.A. and Guezzen, B. (2014) Liquid-Liquid Extraction of Cd (II) by the 1-Methylimidazolium Di(2-Ethylhexyl) Phosphate Task Specific Ionic Liquid. Journal Catalyse Material Environnement, XI, 1-7. http://www.amcemorocco.ma/index.html

[33] Vogel, A.I. (1989) Book. In: Jeffery, G.H., Bassett, J., Mendham, J. and Denney, R.C., Eds., Vogel's Textbook of Quantitative Chemical Analysis, 5th Edition, Longman Scientific and Technical, Harlow, 582.

[34] Xiong, C.H., Yao, C.P., Wang, L. and Ke, J.J. (2009) Adsorption Behavior of Cd(II) from Aqueous Solutions onto Gel-Type Weak Acid Resin. Hydrometallurgy, 98, 318-324. http://dx.doi.org/10.1016/j.hydromet.2009.05.008

[35] Nayl, A.A. (2010) Extraction and Separation of Co(II) and Ni(II) from Acidic Sulfate Solutions Using Aliquat 336. Journal of Hazardous Materials, 173, 223-230. http://dx.doi.org/10.1016/j.jhazmat.2009.08.072

[36] Puigdomenech, I. (2006) HYDRA (Hydrochemical Equilibrium-Constant Database) and MEDUSA (Make Equilibrium Diagrams Using Sophisticated Algorithms) Programs. Royal Institute of Technology, Stockholm. http://www.kemi.kth.se/medusa/

[37] Leo, A., Hansch, C. and Elkins, D. (1971) Partition Coefficients and Their Uses. Chemical Reviews, 71, 525-616. http://dx.doi.org/10.1021/cr60274a001

[38] Nechab, B. and Villemin, D. (2000) Use of a New Hydrophilic Phosphine: DPPPA. Rapid and Efficient Heck Reaction in Aqueous Medium under Microwave Irradiation. Journal of Chemical Research, 2000, 429-431.

[39] Viswanadhan, V.N., Ghose, A.K., Revankar, G.N. and Robins, R.K. (1989) Atomic Physicochemical Parameters for the Three Dimensional Structure Directed Quantitative Structure Relationships 4. Additional Parameters for Hydrophobic and Dispersive Interactions. Journal of Chemical Information and Computer Sciences, 29, 163-172. http://dx.doi.org/10.1021/ci00063a006 
[40] Didi, M.A., Elias, A. and Villemin, D. (2002) Effect of Chain Length of Alkane-1-Hydroxy-1,1'-Methyldiphosphonics Acids on the Iron(III) Liquid-Liquid Extraction. Solvent Extraction and Ion Exchange, 30, 408-415.

[41] Wionczyk, B. and Apostoluk, W.C. (2004) Solvent Extraction of Cr (III) from Alkaline Media with Quaternary Ammonium Compounds. Part II. Hydrometallurgy, 72, 195-203. http://dx.doi.org/10.1016/S0304-386X(03)00139-7 